\title{
Conflict Transformation and History Teaching: Social Psychological Theory and Its Contributions
}

\section{Charis Psaltis, Mario Carretero and Sabina Čehajić-Clancy}

It is widely recognized that the number of international wars has declined continuously since the mid-1960s, whilst internal conflicts and civil wars became more numerous than those fought between nation states. Internal divisions of societies and separatism within a single political unit have also become a more frequent form of conflict. The nature of armed conflicts is also changing claiming the lives of more civilians compared to military personnel in relation to the past (Hobsbawm 2002). As Kelman (2004, 2008) convincingly argued, this changing nature of wars ignited the recent research interest in the notion of reconciliation. In such a context the primary challenge is for former enemies

C. Psaltis $(\square)$

Social and Developmental Psychology, University of Cyprus, Nicosia, Cyprus e-mail: cpsaltis@ucy.ac.cy

M. Carretero

Cognitive Psychology, Autonoma University of Madrid, Madrid, Spain

S. Čehajić-Clancy

Social and Political Psychology, Sarajevo School of Science and Technology, University Sarajevo, Sarajevo, Bosnia and Herzegovina

(C) The Author(s) 2017

C. Psaltis et al. (eds.), History Education and Conflict Transformation, DOI 10.1007/978-3-319-54681-0_1 
to find the way to not only live together peacefully but even at times cooperate and share power.

Today, almost two decades in the twenty-first-century humanity is witnessing both a revival of nationalism, separatism, sectarianism, terrorism and radical fundamentalism and proxy wars resulting in a vast number of casualties, refugees and internally displaced people. Despite the changing nature of these conflicts, it is clear that representations of the past and history teaching are still weaponized for these collective struggles (Bentrovato et al. 2016; Carretero 2011). Given the circumstances, the time is ripe for the human kind to take stock of the knowledge gained from the study of peace and conflict in the social sciences and in particular of the way history teaching and representations of the past are used and abused in this context. In order to enable this process, we ought to systematically understand the process of conflict transformation, the influences exerted by the past and more specifically the contributions made by the field of social psychology.

\section{Conflict Transformation, Conflict Resolution and Reconciliation: The Social Psychological Perspective}

The recent turn in the study of peace and conflict towards "conflict transformation" rather than "conflict resolution", being the process of reaching a durable and mutually satisfactory solution between former enemies (Kelman 2008), is a desired development because such a shift contributes to a greater understanding of the conflict context whilst focusing on more productive aspects of the conflict. In comparison the conflict resolution approach can be regarded as more restrictive in scope (Galtung 2000; Lederach 1997). Conflict transformation puts emphasis not only on the end of direct violence but rather a constant orientation to positive peace and the end of structural (e.g. inequality, social exclusion and exploitation) and cultural forms of violence (e.g. perceived realistic and symbolic threats, prejudice, distrust). In other words, conflict transformation is concerned with transforming the systems, structures and relationships that give rise to violence and injustice.

All available theoretical models of conflict transformation that go beyond conflict management and conflict resolution (Galtung 2000; 
Lederach 1997) emphasize the importance of understanding the processes that enable the transformation of conflict from its destructive and violent forms into a more productive form which is recognized as part of our everyday life to be resolved through dialogue, creative and peaceful means; conflict resolution and conflict transformation are not antithetical and the notion of transformation in the post-conflict period is often presented as a stepping stone to resolution, especially in the case of protracted conflicts (Constantinou 2015).

A notion that occupies a crucial role in both approaches is the notion of reconciliation as both a process and an outcome that not only diminishes the possibility for violent conflict in cases of structural inequalities and political instability but also facilitates peace settlements and supports their viability afterwards. Social psychological concepts and theories are recently making a unique contribution to our understanding of reconciliation. Kelman $(2004,2008)$ proposes a notion of reconciliation from a social psychological perspective beyond any religious connotations. In this context, reconciliation is of vital importance not only for reaching a peace settlement that will bring up a sense of justice and redress of inequality issues but also for its future viability through the cultivation of the element of trust (Marková and Gillespie 2012; Psaltis 2012a). Čehajić-Clancy et al. (2016) conceptualize intergroup reconciliation as an emotion-regulation process involving positive affective change towards the outgroup, and they offer a framework that integrates the emotion regulation and intergroup reconciliation literatures. In this account, the emotions of intergroup hatred and anger towards the outgroup need to be downregulated, whereas guilt for ingroup wrongdoings, hope and empathy need to be upregulated for deep psychological changes to be made possible. These psychological changes include alterations in beliefs, emotions, identity and behavioural intentions. Such an approach is premised on Intergroup Emotions Theory by Smith (1993) who argued that when group memberships are salient, people can feel emotions on account of their group's position or treatment, even if they have had little or no personal experience of the actual intergroup situations themselves. Behind Smith's (1993) theory is the by-now classic Social Identity and Self-categorization theory (Tajfel and Turner 1979) which informs a great number of research in the social psychology of intergroup relations.

Seeing reconciliation as simply an emotional regulation process was criticized for reducing reconciliation into a psychological and 
individualistic process not recognizing the need for structural and societal transformation (Vollhardt and Twali 2016; Shnabel and Ulrich 2016) which is part of what we described earlier as the broader process of conflict transformation. From a social representations perspective (Psaltis 2012a) reconciliation as a process and outcome entails the shift from an identity position in the representational field of mistrust, high prejudice, low quantity and quality contact, low perspective taking, low forgiveness and high threats (realistic and symbolic) into a position of high trust, low prejudice, high quantity and quality of contact, high perspective taking, high forgiveness and low threats (realistic and symbolic). Intergroup contact is also of crucial importance as the motor of change in microgenetic processes of representational change in social interaction (Psaltis 2015b) which is both constrained and enabled by the legal macro-structures and infrastructures of peace and their representations. In this process, the building of trust occupies a central position as it is an organizing principle of the representational field altogether being both a predictor and outcome of intergroup contact. Similar formulations were proposed by Nadler and Shnabel (2015) who also recognize the crucial position of trust in the reconciliation process which they define as both a process and outcome that concerns structural, relational and identityrelated transformations.

An important idea behind theories that study transformative processes is that they understand social or national identity and representations as socially constructed and they are compatible with recent developments in social and developmental psychology (Duveen 2001, 2002, 2007; Psaltis et al. 2015) that aim at the study of human and societal change as the transformation of social relations. Such approaches have the potential to overcome the often narrow perspective of the classical Social Identity Theory (Tajfel 1978) which is mostly interested in categorization processes and offers limited insight into the role of social representations of the past in the formation of intergroup relations.

Still, most of the findings of intergroup relations research today is indeed trying to explain the creation of prejudice, negative stereotyping and the escalation of conflict by putting emphasis on the central role of categorization (Tajfel 1978) and social identification processes but often overlooking the content of these categorizations (Psaltis and Cakal 2016). Ingroup identification processes often lead to emotions on behalf of their group and/or group's actions. Events and situations that affect the group have an effect for the self as well. In (post-)conflict situations, such emotions 
stemming from group's actions or those oriented towards out groups such as intergroup anxiety directly impact intergroup interactions and contribute to further divisions and polarizations. Consequently, assumptions and implications as postulated by the Theory of Intergroup Emotions (Smith 1993) and the model of intergroup anxiety in the Intergroup Threat Theory (Stephan et al. 2009; Psaltis et al., Chap. 4) are highly relevant in understanding conflict transformation. In the present volume, we aim to shed light on how social representations of the past and history teaching in particular could be related to all these social psychological concepts.

To sum up, after political transition periods, successful conflict resolution or cessation of the conflict, war, colonialism and a genocide itself, societies are left with many questions such as disputes over the understanding of the past, issues of identification, responsibility, victimization and justice. These and similar issues ought to be addressed not only from a historical and legal or transitional justice perspective but also from a social psychological angle which concerns itself with issues of ameliorating intergroup relations. How do various actors involved in the process of history teaching (teachers, ministries of education, civil society organizations, historians) see these issues in relation to a social psychological understanding of reconciliation which implies both a process of positive changes in relations between adversaries and an outcome characterized by humanization, acceptance of both similarity and difference, outgroup malleability (Halperin et al. 2011), responsibility for ingroup past wrongdoing (Leach et al. 2013), intergroup contact, prejudice reduction and the cultivation of trust? These processes of humanization, empathy, intergroup contact and dialogue are just a few socio-psychological pillars which can help individuals and groups to become more inclusive, openminded and accepting of the Other and as a consequence contribute to sustainable peace (Čehajić and Brown 2010). To what extend could they inform in any way the various approaches to history education currently in use in various post-conflict or post-transition settings?

\section{Representations of the Past, History Teaching ApProaches and ReCONCILIATION}

One aspect of the reconciliation process concerns primarily the existence of present co-operative relations between individuals and institutions through intergroup contact for a common goal (described 
as the instrumental route to reconciliation by Nadler and Shnabel 2015). Another part concerns the conflict resolution and peace settlement efforts that are usually future oriented (Tint 2010a, b) as they strive to build a common vision or design new institutional structures of power sharing (Loizides 2015) that will resolve structural inequalities. However, at the heart of the reconciliation effort the primary orientation concerns the past and its representations, or what is called by Nadler and Shnabel (2015) the socio-emotional route to reconciliation (apologies, forgiveness, guilt/shame). In this sense, the social representations of a group or a community about the past are directly related to processes of conflict transformation and reconciliation. For example in August 2016 on the 30th anniversary of the killing of "Yoyes", and six years after the last ceasefire by ETA, public discussion in newspapers shows that in the Basque Country three positions around this killing were still evident: (a) the people who condemn this killing; (b) the people who still approve it; and (c) the people who think that it is not possible to make a moral judgement.

These representations of the past (Liu and Hilton 2005; Psaltis 2016) have also been discussed in the social sciences as historical culture (Carretero et al. 2017), which expresses another way of approaching and understanding the effective and affective relationship that different groups have with its past. In this vein, the notion of culture should be best understood as a system of social representations (Duveen 2007; Psaltis 2012b) thus avoiding any fossilized, reified or essentialist connotations that often go with the notion of "culture". Representations of the past describe a dynamic process of dialogue, through which interpretations of the past are disseminated, negotiated and debated between perspectives from academic history, school history and public history (monuments, commemorations, museums, films, historical novels, etc.) (Papadakis 2008; Carretero, Chap. 14).

In this vein, an important question is the following: "What is the place of representations of the past and history teaching in reconciliation?" It has rightly been argued (Cole 2007) that representations of the past and history teaching could be used to either facilitate conflict transformation processes or to block conflict transformation and even reinforce antagonism and conflict through the traditional romantic role of the promotion of blind and essentialist forms of patriotism (Carretero et al. 2012). In countries where the traumatic experiences of identity-based conflict are recent, there are questions about whether, how and at what age children 
should learn about parts of the nation's past relating to conflict (Cole 2007) which naturally influences the curriculum aims, content to be taught and textbooks or supplementary teaching material to be used in the classroom.

A recent review of how the history of the conflict is dealt in postconflict societies (Paulson 2015) revealed that depending on the conflict setting one can identify various approaches to history education. For example, there are conflict settings where guidance on recent conflict is included in national curricula and where it is not thus letting teachers deal with these issues without any direction. Some post-conflict settings saw the establishment of moratoria, namely where they temporarily suspend history education or its recent history segment, including its textbooks (Bentrovato, Chap. 2; Bentrovato et al. 2016) like Afghanistan, $\mathrm{BaH}$, Cambodia, Guatemala, Lebanon or Libya. It is worth noting that in most of these countries one can find a very weak tradition of history teaching methodology which makes history teaching an unlikely candidate to contribute to a transformative process. An interesting case is that of Northern Ireland. Here there is silence regarding the recent history of conflict as until recently they did not have compulsory national curriculum content about recent conflict. In Northern Ireland however, due to the long and quite strong tradition of "New History" (see Carretero, Chap. 14) students have the chance to cultivate their historical thinking skills through an evidence-based, analytic approach that emphasizes multiple perspectives. In particular, the cultivation of historical thinking mostly concerns the development of "historical literacy", gaining a deep understanding of historical events and processes through active engagement with historical texts, establishing historical significance, identifying continuity and change, analysing cause and consequence, taking historical perspectives and understanding the ethical dimensions of historical interpretations (Seixas 2004).

However, according to Kitson (2007) and McCully and Barton (2010) this disciplinary approach is not enough to facilitate reconciliation (McCully 2012; McCully and Reilly, Chap. 12). Many times students assimilated the other community perspective to their own community narrative, and at others, they were completely dismissive of community histories not being able to reflect on the connections between the past and present in regard to their national identities in the context of the collective struggles of their communities and the identity politics around it. 
As a remedy, they argue for the need for a more interdisciplinary approach to history teaching that benefits from the social psychological literature of the study of intergroup relations (McCully and Reilly, Chap. 12). From this perspective, what is needed is a curriculum that attends more directly to the student's active construction of historical meaning and supports them in constructing critical perspectives on the contemporary relevance of the past through the cultivation of emotional empathy for the outgroupers. It is also important to understand through Social Identity Theory (Tajfel 1978) how simplistic binary oppositions are created through categorizations and the consequences of that for the formation of homogenizing views of the ingroup and the outgroup. Students must be helped to understand why some people feel the need to use and abuse history. Recent social psychological work offers one possible answer to this question. Smeekes et al. (2017) show that in both Northern Ireland and Cyprus when individuals experience a perceived sense of realistic or symbolic or identity threats (Branscombe et al. 1999) it becomes more likely that they attempt to regain a sense of ingroup pride through recourse to a sense of collective continuity (Sani 2008; Smeekes 2015; Smeekes and Verkuyten 2015). Recent studies have pointed out that the continuity motive is an important part of various types of group identity (e.g. Easterbrook and Vignoles 2013) and plays an important role in intergroup relations (e.g. Smeekes and Verkuyten 2015). It has, for example, been shown that collective selfcontinuity forms an important basis for national identification, but at the same time drives ingroup defensive reactions in the context of group threat (Smeekes and Verkuyten 2015) by creating more negative attitudes towards immigrants.

In other words, representations of the past premised on notions of continuity relate to fears of a threatened political or financial status of the ingroup or an identity threat coming from the other group. This dynamic helps us understand the mechanisms behind the phenomenon of resistance (Duveen 2001) when microgenetic processes (Duveen and Lloyd 1990; Psaltis 2015b) of engagement with alternative perspectives and representations of the past are made possible but often undermined by the use of semantic barriers who defend the self from change (Gillespie 2008, 2015).

On the other hand, as it is shown by Psaltis et al. (Chap. 4) in the post-conflict context of Cyprus, Serbia and Croatia, the threats themselves are heightened by internalization and adherence of the official 
master narratives of conflict in all three contexts; through a heightened feeling of threat, distrust between ingroup and outgroup is also increased, thus becoming a major impediment to reconciliation. This kind of research leads to the conclusion that essentialist representations of the past and an ahistorical conception of essentialist and reified national identifications can entrap individuals and societies into a vicious circle of frozen or even escalated conflict (Makriyianni and Psaltis 2007).

In post-conflict settings where the state decides to indeed offer guidelines for the history of conflict in their curriculum and textbooks this is, in the majority of cases, done in a manner that blocks conflict transformation or event reinforces conflict by insisting, even after educational reforms taking place in the twenty-first century, on a culture of preservation of the memory of conflict and a simplistic master narrative of the conflict. This is the case, for example, in Israel (Bekerman and Zembylas 2011) and Cyprus for both the Greek Cypriot and the Turkish Cypriot community (Klerides and Philippou 2015; Makriyianni et al. 2011; Perikleous 2010; Psaltis 2015a, b; Zembylas and Karahasan, Chap. 13) with directions pointing to the need for a preservation of the memory of one-sided victimization and an ethnocentric orientation to history teaching. In the case of Cyprus, as in the case of Israel, this gap is successfully filled by the work of local NGOs who work either intercommunally like the Association for Historical Dialogue and Research (AHDR) or monocommunally and in co-operation with international organizations like the Council of Europe promoting the idea of a transformative form of history teaching that cultivates both the critical historical thinking skills of the students (Seixas 2004; Wineburg 2001; Carretero, Chap. 14) and reconciliation through a critical approach to ethnocentric master narratives. The pioneering approach of $\mathrm{AHDR}^{2}$ has been one that deals with both non-controversial social history-like the supplementary teaching material produced by teachers from both communities and international experts, called $A$ look at our past published in English, Greek and Turkish from a multi-perspective approach-and controversial issues like approaching the issue of the missing people (Chapman et al. 2011 ) by applying a multiperspectivity approach. AHDR is a pioneer of the interdisciplinary and transformative approach to history teaching as its work has been enriched by social psychological and developmental theory from its very first steps (Makriyianni and Psaltis 2007). It is noteworthy that in the last decades an international "eduscape" (Klerides and Zembylas 2017) is expanding where the disciplinary approach to 
history teaching is used as a way to achieve conflict transformation aims supported by various international organizations: Council of Europe, UNESCO and OECD (Bentrovato, Chap. 2). The contribution of various local and international NGOs like EUROCLIO has been instrumental in this effort (Bilali and Mahmut, Chap. 3; McCully and Reilly, Chap. 12).

However, not all efforts towards reconciliation have treated history teaching with respect for critical historical enquiry since some postconflict societies following the early example of the Franco-German textbook decided simply to delete from textbooks offensive sentences or material (e.g. $\mathrm{BaH}$ ) or harmonizing conflicting narratives through a process of political negotiation which was the result of a political compromise rather than that of critical enquiry. In some cases they even decided to promote a nation building approach, by writing up a single authoritative narrative; this is the case of Rwanda where the government enforced a new, hegemonic narrative of past events, applying a narrow understanding of what is to be taught. This narrative promotes the concept of "Rwandanness", emphasizing the nation's alleged primordial unity and dismissing ethnic identities as a historically unfounded colonial invention that was supposedly the primary cause of genocide in Rwanda (Bentrovato, Chap. 2). Despite the epistemological weaknesses of single-narrative approaches, there is an emerging realization that common history textbook commissions (Korostelina and Lässig 2013), provided they respect the principles of cultivating historical thinking skills, can indeed produce valuable textbooks or supplementary teaching material. Moreover, probably the most significant contribution of joint textbook commissions is the performative and transformative aspects of the co-operative writing up itself (Pingel, Chap. 9). This is only expected from the social psychological and wellestablished paradigm of prejudice reduction through intergroup contact (Allport 1954; Brown and Hewstone 2005; Tausch et al. 2010) given its potential to deconstruct negative stereotypes, facilitate perspective taking and forgiveness, reduce threat and intergroup anxiety, and more importantly build trust.

It could be claimed that depending on the implicit lay social psychological theories of change or practice, and conflict transformation processes held by both practitioners in civil society (Bilali and Mahmut, Chap. 3) variations in the strategies followed to tackle representations of the past can also be expected at the level of civil society initiatives. 
The NGOs usually try to find ways to fill the gaps of silence, evasion and elision in official history textbooks and curricula. This is because civil society actors are less constrained by the pressures and political agendas that elites and governments face; for example, in Cyprus NGOs like the AHDR are not constrained by the inability of the internationally recognized ministry of education and culture of the Republic of Cyprus to officially co-operate with the corresponding ministry in the Turkish Cypriot community which is internationally recognized only by Turkey. NGOs like AHDR in Cyprus or History that Connects project which invites history educators from Bosnia, Croatia, and Serbia to co-operate are usually engaged in professional development and capacity building for teachers. This kind of teacher training focuses on innovative pedagogies and methods, oral histories, digital media, production of educational materials to supplement traditional textbooks that incorporate new pedagogies and more inclusive historical experiences across conflicting groups. They also often get involved in the creation of forums for dialogue like the building of educational centres $^{3}$, seminars or conferences to foster co-operation among teachers across division, conflict lines or borders.

What civil society organizations are aiming at is to transform the social representations at the grassroots level by deconstructing master narratives and overcoming ethnocentric representations of the past. Sometimes NGOs explicitly aim at raising awareness of the dynamics of intergroup conflict and the social psychological and other roots of conflicts. At other times according to Bilali and Mahmoud (Chap. 2) they engage in oral history projects so that they bring in the public eye personal histories of traumatization of victims of the conflict or the perspectives of members of marginalized or oppressed groups.

Most local and international NGOs prioritize teacher training because educators are the main mediators between historiographical traditions, school history in the classroom and public history. Depending on the specific country they could be trained as historians or not, be trained in history didactics or not. When such pre-service training is absent, they often function more as "lay historians" (Klein 2013) than academic historians. This could in fact be one of the greatest impediments for successful conflict transformation since their teaching will be constrained by social representations of the past that take the form of master narratives of the conflict (Carretero 2011; Bar-Tal and Salomon 2006; Páez and Liu 2011; Psaltis 2012a, 2016). 
Unfortunately, actual teaching practice in many post-conflict societies ends up enhancing collective memory or collective remembering (Wagoner 2015) of victimization, and promoting exclusive and essentialist views of patriotism and national identities (Carretero 2011; Hein and Selden 2000) by teaching the past as an ontological and fixed "heritage" (Lowenthal 1996; Makriyianni and Psaltis 2007) which promotes notions of cultural continuity, nativist or autochthony beliefs of the kind "We were here first" (Martinovic and Verkuyten 2013) regret for a decadent present and nostalgia for a better past (Smeekes and Verkuyten 2015). This is done at the cost of challenging such simplistic representations of the past that Moscovici would call Social Representations based on belief ${ }^{4}$ (Moscovici 1998/2000; Psaltis 2016). Such representations are often polemical and are enacted through forms of communication that Moscovici (1961/2008) described as propaganda (Kello and Wagner, Chap. 8) in his seminal work on social representations of psychoanalysis.

The "charters" (Liu and Hilton 2005) on which collective memory (Páez and Liu 2011) master narratives as social representations (Psaltis 2016) of the past are structured serve identity functions, on the basis of either glorification or victimization. Interestingly both notions strengthen an ethnocentric perception of the past that contributes to distancing from other groups and thus not only obstruct conflict transformation but also limit the cultivation of historical thinking as they distort students understanding of significance in favour of events and characters relating to what is perceived as the ingroup at any given time, they also distort understanding of continuity and change, through the use of simplistic circular and Rise-and-fall views of history or linear progression schemes (Páez et al. 2017). They also obstruct the understanding of causality through the romantic or great men perspective and the use of historical analogies and deterministic or attribution schemes that fail to capture contingence, randomness and multi-causality (Carretero, Chap. 14). An attribution style which is characteristic for its ingroup serving bias and its pernicious effects is what has been described by Thomas Pettigrew (1979) as the ultimate attribution error which is the tendency to internally attribute negative outgroup and positive ingroup behaviour and to externally attribute positive outgroup and negative ingroup behaviour. Similarly, such master narratives feed moral disengagement from past wrongdoings of the ingroup (Bandura 1999; Bilali 2013 ) by moral justification of the act, denial, displacement, or diffusion of responsibility, disregarding or minimizing the negative consequences 
of the violent acts, and attribution of blame to the victim or circumstances. Finally, this kind of representations of the past often actively promote a sense of intergroup competitive victimhood (Noor et al. 2012) which describes the efforts of members of groups involved in violent conflicts to establish that their group has suffered more than their adversarial group which is a mindset that obstructs reconciliation efforts and the support of peace processes.

\section{Tensions and Dilemmas Arising from Asymmetrical Post- CONFlict Contexts for History Teaching}

Given that conflict transformation engages issues of structural inequality and justice it is also necessary to think about conflict settings where one could argue that competitive victimhood is less likely to be germane because there is clear division, or at least wider consensus, between either the roles of perpetrator and victim or a clear case of structural inequalities favouring one (e.g. a majority) over the other group (e.g. a minority). Such settings are discussed in the papers by Barreiro et al. (Chap. 5) in the case of the Mapuche minority group who struggle for recognition from the majority group in Argentina. It is also discussed by Leone (Chap. 6) in the case of colonial Italy (cf. Licata and Klein 2010 on the Belgium heritage of colonialism) facing the past wrongdoings of their ingroup in Ethiopia. Also, Bilewicz et al. (Chap. 7) discuss how to best deal with the Holocaust in the context of history teaching.

In such cases, whenever an asymmetrical dynamic of majority-minority or perpetrator-victim dynamic enters the scene interesting tensions become relevant on how to best deal with history and representations of the past. One kind of tension is when minority counter-narratives fall back to the use of simplistic narratives themselves, or enter into an identity politics of strategically using reified (Hammack 2010) or essentialist identities (Zeromskyte and Wagner 2016) to gain public awareness or "preserve" what they see as their identity (Barreiro et al., Chap. 5) which is also one of the strategies sometimes used by NGOs in some parts of the world. Such examples are instructive because they help us clarify the cases when the cultivation of historical thinking skills might not be served by what is perceived as working towards reconciliation (Bilali and Mahmut, Chap. 3). 
In social psychological theory, recent debates reflect exactly these tensions when the prejudice reduction paradigm is pitted against the collective action model. Research interest in collective action was rekindled, albeit in its more radical and revolutionary form, after the so-called Arab spring revolutions with the proposal of new social psychological models of collective action (Van Zomeren et al. 2008) which tried to identify the conditions under which various groups embark on collective action, or even become radicalized engaging in violent forms of struggle. Social identity processes have been identified as a crucial ingredient in understanding such collective actions. Recent theories of collective action suggest that a feeling of relative deprivation, strong identification with the ingroup and group efficacy are key predictors of collective action on behalf of the ingroup (Van Zomeren et al. 2008). But here exactly lies some of the most recent tensions in the field of Social Psychology as it would appear that what is being proposed by collective action theorists is the contestable claim that groups who have an ethically legitimate struggle to wage, as that of ending structural violence could or should be agitating, activating or facilitating exactly the same social psychological mechanisms that the prejudice reduction and reconciliation literature, discussed earlier, has been criticizing for years or exposing as unproductive in processes of conflict transformation (see debate in Dixon et al. 2012).

Some of the collective action theorists even went as far as to argue that the promotion of strategies for emancipatory action to end structural inequalities against the oppressed minorities is incompatible with the promotion of co-operative relations between the groups and the well-established paradigm of prejudice reduction through intergroup contact (Brown and Hewstone 2005) because prejudice reduction interventions might be working towards regimenting a structural inequality in society by reconciling the weak group with an unfavourable for them status quo (Dixon et al. 2012). Indeed the same mediators of prejudice reduction and reconciliation through intergroup contact (threats, intergroup anxiety, stereotyping) (Stephan et al. 2009) could be used in the reverse direction in the collective action paradigm to enhance solidarity and cohesion within the dominated group, facilitating sacrifices (even giving one's life for the ingroup). In that sense the revolt model of social relations implied in the collective action paradigm (usually studied in the context of overthrowing totalitarian regimes or dictatorships as we have recently seen in the Arab spring revolts or in the eighties against authoritarian leaders in the Eastern Europe) appears at first glance to be a whole 
different context where non-normative, violent action and the escalation of conflict would even be seen as legitimate. However, this rationale despite its positive role in bringing to our attention the issue of structural inequality, moving away from individualist assumptions, is built on some problematic premises: first, it presupposes that the oppressed have a false consciousness and do not know what is best for them (Howarth et al. 2012). Secondly, the whole argument is built on a very weak ethical standpoint because the logical conclusion of it is that the oppressed in fact need to keep their simplistic conflict narratives intact and their low-level historical thinking or consciousness just to end up instruments of some enlightened elites that would guide them to go sacrifice themselves for the common good. What collective action theorists failed to discuss is also the applicability of such a model in Western democracies, post-conflict or divided societies and the similarities of forms of representation produced through collective action with historically well-rehearsed doctrines and ideologies like nationalism, racism, fundamentalism and extremism (see Obradovic and Howarth 2017; Psaltis et al. 2015). For example, in divided societies like Israel and Palestine, Northern Ireland, Serbia, Croatia or Cyprus (Psaltis et al., Chap. 4) "two can play that game" of collective action for the interest of the ingroup that will eventually lead to either stalemate or the escalation of conflict, without compromise or reconciliation (Psaltis 2012a). The critics of the "prejudice reduction" paradigm (Dixon et al. 2012) also failed to recognize the existence of joint ingroup-outgroup collective action for the benefits of both groups by segments of former enemy groups for which intergroup contact and co-operation is actually a necessary precondition for joint collective action. Finally, they did not recognize post-colonial writings that argue along the emancipation of both groups in the process of tackling structural inequalities (Howarth et al. 2012).

The negative consequences of strategic decisions to use essentialist representations of the past or reified identities for collective struggles in asymmetric contexts relating to nation building efforts of new states can be seen in differing degrees in the context of the Baltic states (Kello and Wagner, Chap. 8) and Belarus (Zadora, Chap. 10) where in a post-transition context just before and after the dissolution of the Soviet Union nationalism was on the rise. In Estonia, a more disciplinary approach to history teaching is becoming more widely accepted after joining the EU, whereas in Latvia a more clear involvement by politicians in history teaching in a similar context led to more references to patriotism as an 
aim of history teaching according to Kello and Wagner (Chap. 8). The situation is more problematic in Belarus where an authoritarian administration is clearly using history teaching for political purposes in a very centralized way. The result of such pressures for the actual teaching practice is that teachers trying to balance a romantic and enlightened way of history teaching end up making use of communicative styles that Moscovici described as "propagation", a communicative style which is a middle road between propaganda and diffusion (Moscovici 1961/2008). Indeed the denial of citizenship rights to a significant number of inhabitants of the Baltic states of Russian origin should not come as a surprise given the link between essentialist representations of the past, ethnic identity and exclusionary notions of citizenship (Kadianaki and Andreouli 2015; Kadianaki et al. 2016).

The fact that the collective action paradigm is premised on predetermined roles of oppressor and oppressed, majority-minority, perpetrator and victim can be also challenged in that groups historically can pass from both roles and thus it is rather unlikely that there will ever be a clear case of a group being constantly in the same position. This problem is very clear in Cyprus, for example, not only because at different times in history both groups were oppressed and oppressors, victims and perpetrators, minorities and majorities but also because Greek Cypriots can always claim that they are the victims of a huge country like Turkey and the Turkish Cypriots at the same time claim that they are the victims of the $80 \%$ of the population (Greek Cypriots) in Cyprus. So in fact there is an interaction of social representations of the Cyprus issue with representations of the past (the main tension being whether it is a problem of intercommunal conflict vs a problem of violation of international law by Turkey which invaded Cyprus) which is not very far from the spirit of competitive victimhood already discussed for its pernicious effects.

\section{From the Disciplinary to the InTERdisciplinary Approach in History Teaching: From Representations of the Past Based on Belief to Representations Based on Knowledge}

History educators have been increasingly realizing the need to deepen their understanding of the role of history teaching in conflict transformation (see Carretero 2011; Perikleous and Shemilt 2011). 
As it will become clear to the reader of this volume, such concerns are now global and historically have their roots in the genetic epistemology of Jean Piaget in the International Bureau of Education (IBE) (Pingel 2016) when he advocated international dialogue of educators in an effort to de-centre history teaching from the ethnocentric orientations in the period between World War I and World War II. In the same vein, the work of the Spanish historian Altamira (1891) earlier was also pioneering for policy on history teaching in the League of Nations. The early epistemological distinctions made by Jean Piaget (1932) between social relations of co-operation (based on mutual respect) and social relations of constraint (unilateral respect/inequality of status) are still as relevant as ever since they offer a robust and clear epistemological social constructivist standpoint (Psaltis et al. 2015) for the construction of historical knowledge and advancement of historical consciousness. Such a conciousness should aim to move away from social relations of constraint towards relations of co-operation as they are enacted in social interaction successfully resolving socio-cognitive conflicts of various perspectives and producing more advanced forms of knowledge (Makriyianni and Psaltis 2007).

In this vein, the discussion of stages of historical consciousness by Rüsen (2004) and the higher form of consciousness described as "genetic" relates to Piaget's higher forms of transformative knowledge and interacting that he described as genuine dialogue characteristic of a democratic mentality. The Moscovician Genetic Model of Social Influence (Moscovici 1976) recognizes the harsh reality of asymmetries and inequalities in the conflict-ridden worlds we live in, but it is largely based on convincing by peaceful means, dialogue and communication the population for the stance of the minority in a struggle for recognition and change of social representations. This model as well as the more recent approach of genetic social psychology (Duveen and Psaltis 2008; Psaltis et al. 2015) recognizes that ideal relations of mutual respect are rarely achieved in reality since social identities are shot through with inequalities of status. However, it recognizes that conflicting asymmetries could create the conditions for productive forms of dialogue that can lead to more advanced forms of thinking. This approach is aiming at the integration of the processes of microgenetic, ontogenetic and sociogenetic changes of social representations; here the forms of communication described Kello and Wagner (Chap. 8) drawing inspiration from the 
second part of Moscovici's Psychoanalysis and the recent work of Gerard Duveen (Moscovici et al. 2013) become directly relevant. The processes of socio-cognitive conflict (Doise et al. 1976) between representations of the past, resistance to change (Duveen 2001) through the use of symbolic resources (Zittoun et al. 2003) and symbolic barriers (Gillepie 2015) discussed in the papers by Barreiro et al. (Chap. 5) can form a vibrant research agenda for the future. The in-depth studies of social interaction by Tsafrir Goldberg (2013; Chap. 11) in relation to the dualnarrative/empathetic textbook approach and the critical/disciplinary approach in Israel suggest that microgenetic processes in the classroom are indeed influenced by a complex interplay between the voices and perspectives made available in textbooks and the asymmetrical status of the groups in conflict.

\section{The Major Challenge: Facilitating Conflict Transformation Through Interdisciplinary Research and Dialogue}

What this volume makes clear is the need for various stakeholders in the process of conflict transformation (policy makers, teachers, civil society and the grassroots) to engage in a process of reconstruction of their representations of the past. This cannot be done by replacing a master narrative with another well-intentioned simplistic peace narrative or with the strategic use of essentialist and reified forms of identity and social representations of the past. What is needed is a history teaching that is epistemologically more advanced compared to collective memory or the teaching of history as heritage (Lowenthal 1996; Makriyianni and Psaltis 2007), not only because more de-centred and multi-perspective forms of knowledge as we know from the genetic epistemology of Jean Piaget are more advanced forms of knowing compared to monoperspective accounts (see Makriyianni and Psaltis 2007) but also because developing the historical literacy, and their epistemological stance of history (Nasie et al. 2014), allows them to take an informed, critical and reflective stance on diverse representations and interpretations of the past. The main message of this volume is that we need to move from the disciplinary to the interdisciplinary teaching of history. History teachers who have enriched their history teaching skills with knowledge of 
social psychological theories will be in a position to engage with historical texts, establish historical significance, identify continuity and change, analyse cause and consequence, take historical perspectives and understand the ethical dimensions of historical interpretations as described by Seixas (2004) in a more successful way as proposed by McCully and Reilly (Chap. 12). Such teaching will enlarge the notion of historical literacy into a study of historical culture (Grever and Stuurman 2007) and historical consciousness (Rüsen 2004) in the classroom so that students become reflective of the role of collective memory and history teaching in processes of conflict transformation and understand the ways in which various forms of historical consciousness relate the past, present and future (Van Alphen and Carretero 2015; Psaltis 2016). This can be done through a better grasp of the way attributions of past wrongdoings (Doosje and Branscombe 2003) relate to processes of moral disengagement, apology, guilt, shame or regret (Imhoff et al. 2012); how realistic and symbolic threats can become an obstacle for prejudice reduction, confidence building and reconciliation; and how intergroup contact can lead to reconciliation. This kind of history teaching is interdisciplinary in nature and can be called transformative history teaching to the extent that it facilitates both the cultivation of historical thinking and conflict transformation.

\section{Part I: Global and Regional Perspectives on Textbook Writing, Civil Society Organizations and Social REPRESENTATIONS}

The first part of this volume discusses the state of the art from an international and regional perspective on developments at the level of policy making and history textbooks in particular, local and international civil society organizations working on reconciliation projects in post-conflict societies all the way down to the representation of the past of lay people.

In her chapter Bentrovato (Chap. 2) examines history textbook work as an intervention for the promotion of reconciliation in intergroup conflict settings. It maps current practices and emerging trends in this field and considers their value and limitations. The analysis, combining a narrative framework with the conflict transformation paradigm, questions the value of models involving narrative evasion or elision and of 
single-narrative approaches and advocates for multi-narrative and multiperspective textbook designs. In proposing a model of collaborative textbook work based on the concept of dialogical narrative transformation, this analysis elucidates its potential value as a catalyst for positive intergroup engagement and dialogue and ultimately for the redefinition of relationships. It thus shows that history textbook writing, often a battleground of narratives and interests, may act as a site and means of conflict transformation.

Bilali and Mahmoud (Chap. 3) review the work of civil society organizations that focus on confronting history as an avenue to achieving intergroup reconciliation in the aftermath of conflict. The chapter sheds light on practitioners' lay theories and strategies to address history for conflict transformation and reconciliation and contrasts these approaches to the scholarship in this area. Bilali and Mahmoud review the impressive number of 127 civil society projects that focus on confronting history in forty-five countries. They draw parallels between practitioners' approaches and the research literature and theory on intergroup conflict and discuss scholarly evidence on the assumptions underlying praxis from a social psychological perspective.

In their contribution in Chap. 4, Charis Psaltis, Renata Franc, Anouk Smeekes, Maria Ioannou and Iris Žeželj explore the role of social representations of the past, known as master narratives, in three cases of post-conflict societies (Cyprus, Serbia, Croatia). Their findings point to a past-present-future connection in all contexts; adherence to official master narratives of conflict relates to threats to ingroup well-being, an exaggerated sense of difference as an identity threat and the attribution of negative intentions to the outgroup today. These various types of threats mediate the negative effects of adherence to master narratives on the building of distrust thus undermining reconciliation.

\section{Part II: Social Psychological Perspectives of Perpetrators and Victims}

The second part of the volume deals with the question of perpetratorvictim dynamic and the ways that master narratives could be resisted in two different contexts (colonialism and holocaust) that however both involve a more widely accepted asymmetric perpetrator-victim dynamic. 
In their contribution (Chap. 5) Alicia Barreiro, Cecilia Wainryb and Mario Carretero discuss the "Conquest of the Desert", a military campaign carried out by the Argentine State at the end of the 19th century, which involved the massacre and enslavement of indigenous communities. They analyse the hegemonic narrative concerning this historical process as conveyed by a museum's exhibits along with the indigenous counter-narrative as registered and supported by the local Mapuche community. Their analysis shows that the hegemonic narrative tends to negate the conflict between the two groups by rendering the indigenous group invisible and representing their identity in an anachronistic fashion. The counter-narrative evidences a tension between indigenous people's need to assert their identification with their ancestors and secure recognition from the dominant group, whilst also allowing for change and transformation in their midst.

In Chap. 6 Giovanna Leone describes what happens when history teaching breaks down social denials of past ingroup wrongdoings. These denials often occur when former victims of past violence are weak or isolated. She argues that reactions to teaching dealing with sensitive historical issues have to be set apart from reactions to teaching dealing with historical facts denied in the general social discourse. The article proposes to consider the latter as a special instance of parrhesia. Foucault's theoretical stance is discussed, who expects that parrhesia may lead to positive effects for listeners able to accept a difficult truth. Then, a case study on reactions by Italians to evidence of socially denied Italian colonial crimes is presented.

Michal Bilewicz, Marta Witkowska, Silviana Stubig, Marta Beneda and Roland Imhoff (Chap. 7) relate their social psychological research to Holocaust education which is one of the most widely taught historical matters: it is present in school curricula as part of history classes, but also in human rights education, ethics, philosophy and general social studies. Yet, many studies point to the fact that Holocaust education is not effective in providing knowledge and raising an emotional approach to this genocide. This chapter reviews empirical research conducted in Germany and Poland showing the main shortcomings of current Holocaust education and interpreting them from a social psychological perspective. Alternatively, they propose three alternative approaches to Holocaust education based on their findings. They suggest (1) using regret- instead of guilt-inducing narratives about the past, based on empathic concern 
about the victim, (2) incorporating moral exemplars narratives and (3) basing the education on local identities rather than national ones.

\section{Part III: Textbook and Teacher Perspectives in Post- transition and Post-Conflict Societies}

The third part focuses on history textbook and teacher perspectives with a special emphasis on the main mediators of history teaching, that is history teachers.

In Chap. 8 Kello and Wagner analyse history teaching through the lens of a distinction of communication styles-dissemination, propagation and propaganda-as proposed by Social Representation Theory. They see a history classroom as a communicative space and history teaching as situated standpoints-in-action. These standpoints can occupy different places on a continuum between the two extremes-dissemination versus propaganda-that is between an academic instruction style, neutrally presenting different perspectives about the past, versus straightforward ideological teaching. The authors analyse interviews with Estonian and Latvian history teachers and show how communication styles are defined both by the teacher's perceived action space, delimited by social, political, educational and academic demands and contexts, and by understandings of the past and history.

Falk Pingel (Chap. 9) focuses on history textbook revision and communicative processes around this practice at different levels. Various international organizations and local stakeholders in education participate in projects on the revision of history textbooks and curricula in conflictridden countries. Falk Pingel examines whether theories of social psychology help explain strategies of intervention. In Bosnia and Herzegovina, it was crucial to overcome ethnic, cultural and religious divides that split the Bosnian society and imprint the whole education system. Whereas at the beginning of the revision process Bosnian participants showed strong ingroup attitudes to protect their ethnic identity, continuous joint work decreased the impact of political difference and increased a common understanding of acting as education experts. Communication no longer went along the model of political negotiation and legitimation but followed the paradigm of an intersubjective, truth-finding process.

In her contribution Anna Zadora (Chap. 10) analyses textbook narratives in the specific context of Belarus-a post-totalitarian and 
authoritarian state. School history teaching has often been a powerful instrument for patriotism and identity building in Belarus. Political authorities tend to control the school history textbook writing and the transmission of sentiment of loyalty to the motherland. History teaching is often used for identity building processes, because history is relating to continuity and stability as fundamental notions for identity building. The article will provide a chronological analysis of the evolution of history textbooks writing in Belarus and the transmission of patriotism discourse trough the history textbooks and the prism of the construction of the dividing line between "us": patriots, belonging to the nation and the "other": "the strangers".

\section{Part IV: Pedagogical Approaches to History Teaching AND ReCONCILIATION}

In the fourth and final part of the volume, the focus moves to various pedagogical practices of history teaching in relation to reconciliation and a comparison of various possible approaches practically taken in formal and non-formal education. Such approaches intend to deal with issues of conflict transformation and reconciliation through history teaching in the post-conflict societies of Israel, Northern Ireland and Cyprus, where an interdisciplinary understanding of history teaching can be found either in civil society organisations or the formal educational system in various degrees.

Tsafrir Goldberg in Chap. 11 describes an intervention where Jewish and Arab Israeli adolescents were randomly allocated to learn the history of the Jewish-Arab conflict in one of three competing history teaching approaches-a single official narrative, an empathetic dual-narrative and a multiple-perspective critical enquiry. Later, Jewish and Arab participants were matched by teaching approach into small groups to discuss the roots and solution to the conflict. Analysis of learners' writing and discussion shows one-sided history teaching reduces openness to outgroup perspective, egalitarian intergroup interaction and reconciliatory decisions. Openness to outgroup perspective and acknowledgement of responsibility predicted reconciliatory interaction and discussion outcome in line with the needs-based reconciliation model.

In Chap. 12, McCully and Reilly discuss the role of history teaching in promoting positive community relations in Northern Ireland with 
specific reference to two publicly funded projects. The Northern Ireland context for history teaching is outlined, followed by an overview of relevant social psychological theory, concepts and research. Educational responses to the conflict and post-conflict situations are explored including development of the history curriculum. The extent to which history teachers might employ ideas from social psychology to contribute to improved relationships between young people is examined. They conclude that history teachers may privilege disciplinary outcomes and curriculum over other project aims; therefore, outcomes in relation to promoting community relations may be less consistent than disciplinerelated outcomes without additional input from social psychologists.

Michalinos Zembylas and Hakan Karahasan in Chap. 13 explore the potential of history teaching in formal and non-formal education spaces to facilitate conflict transformation processes, focusing on the role of dangerous memories and reconciliation pedagogies. The chapter is divided into four parts. First, there is a theoretical discussion on memory, history and identity in relation to dangerous memories and conflict transformation. Second, a brief review of recent formal reform efforts on history teaching is provided in the Greek Cypriot and Turkish Cypriot educational systems. Third, the work of NGOs working with both Greek Cypriot and Turkish Cypriot teachers shows some openings for reconciliation pedagogies and dangerous memories. The chapter ends with a broader discussion of the role that could be played by reconciliation pedagogies to promote dangerous memories through both formal and nonformal education efforts.

The concluding chapter written by M. Carretero, a co-editor of the volume, draws on his experience on history teaching in relation to patriotism, nationalism, social identity processes and reconciliation in various parts of the world. It tries to be a reflective commentary establishing a meaningful relation between present trends in history education and how to rethink them in relation to the teaching of historical contents in post-conflict societies. Therefore this chapter tries to focus not only on what to teach but also on how to teach it and how this could contribute to conflict transformation. Also, this chapter intends to develop a meaningful relation between social psychology contributions and present ideas coming from history education, historiography and related fields. 


\section{Notes}

1. Yoyes was an ETA terrorist that decided to abandon the terrorist actions and was later killed by her former terrorist colleagues. Story retrieved from El Pais newspaper (http://politica.elpais.com/politica/2016/09/21/ actualidad/1474483613_429957.html).

2. In recognition of its pioneering work at the level of civil society organizations, AHDR has recently been awarded with the Max van der Stoel Award of OSCE in 2016 (http://www.osce.org/hcnm/256056).

3. In Cyprus, the major project of the AHDR was the establishment of the Home for Co-operation (http://www.home4cooperation.info/). A renovated derelict building in the Nicosia UN patrolled Buffer Zone to be used as an educational centre and meeting place for AHDR and other intercommunal NGOs working for reconciliation and co-operation between the two communities in Cyprus.

4. Moscovici's (1998/2000, p. 136) distinction is between (a) social representations "whose kernel consists of beliefs which are generally more homogenous, affective, impermeable to experience or contradiction, and leave little scope for individual variations" and (b) social representations founded on knowledge "which are more fluid, pragmatic, amenable to the proof of success or failure, and leave a certain latitude to language, experience, and even to the critical faculties of individuals"; this distinction clearly relates back to his social influence model of minority influence and through that to Piaget's $(1932 / 1997)$ social psychological model of relations of constraint vs relations of co-operation.

\section{REFERENCES}

Allport, G. (1954). The nature of prejudice. Cambridge, MA: Addison-Wesley.

Altamira, R. (1891). La enseñanza de la Historia (History education). Madrid: V. Suárez.

Bandura, A. (1999). Moral disengagement in the perpetration of inhumanities. Personality and Social Psychology Review, 3, 193-209.

Bar-Tal, D., \& Salomon, G. (2006). Israeli-Jewish narratives of the IsraeliPalestinian conflict: Evolvement, contents, functions and consequences. In R. I. Rotberg (Ed.), Israeli and Palestinian narratives of conflict: History's Double Helix. Bloonington: Indiana University Press.

Bekerman, Z., \& Zembylas, M. (2011). The emotional complexities of teaching conflictual historical narratives: The case of integrated Palestinian-Jewish schools in Israel. Teachers College Record, 113(5), 1004-1030. 
Bentrovato, D., Korostelina, K. V., \& Schulze, M. (Eds.). (2016). History can bite: History education in divided and postwar societies. Göttingen: V\&R Unipress.

Bilali, R. (2013). National Narrative and Social Psychological Influences in Turks' Denial of the Mass Killings of Armenians as Genocide. Journal of Social Issues, 69, 16-33.

Branscombe, N. R., Ellemers, N., Spears, R., \& Doosje, B. (1999). The context and content of social identity threat. In N. Ellemers, R. Spears, \& B. Doosje (Eds.), Social identity: Context, commitment, content (pp. 35-58). Oxford, United Kingdom: Basil Blackwell.

Brown, R., \& Hewstone, H. (2005). An integrative theory of intergroup contact. In M. Zanna (Ed.), Advances in experimental social psychology (Vol. 37, pp. 255-343). San Diego, CA: Academic Press.

Carretero, M. (2011). Constructing patriotism. Teaching history and memories in global worlds. Charlotte: Information Age Publishing.

Carretero, M., Asensio, M., \& Rodriguez-Moneo, M. (Eds.). (2012). History education and the construction of national identities. Charlotte: Information Age Publishing.

Carretero, M., Berger, S., \& Grever, M. (2017). Introduction: Historical cultures and education in transition. In: Carretero, M., Berger, S., \& Grever, M. (Eds.). (2017). Palgrave handbook of research in historical culture and education (pp. 1-35). Basingstoke: Palgrave.

Čehajić, S., \& Brown, R. (2010). Silencing the past: Effect of intergroup contact on acknowledgment of ingroup atrocities. Social Psychological and Personality Science, 1(2), 190-196.

Čehajić-Clancy, S., Goldenberg, A., Gross, J., \& Halperin, E. (2016). SocialPsychological interventions for intergroup reconciliation: An emotion regulation perspective. Psychological Inquiry, 27(2), 73-88.

Chapman, A., Perikleous, L., Yakinthou, C., \& Zincir Celal, R. (2011). Thinking historically about missing persons: A guide for teachers. Nicosia: AHDR.

Cole, E. (Ed.). (2007). Teaching the violent past: History education and reconciliation. Lanham, MD: Rowman and Littlefield.

Constantinou, C. M. (2015). Conflict transformation and homodiplomacy. In C. Psaltis, A. Gillespie, \& A. N. P. Perret-Clermont (Eds.), Social relations in human and societal development (pp. 114-133). London, United Kingdom: Palgrave Macmillan.

Dixon, J., Levine, M., Reicher, S., \& Durrheim, K. (2012). Beyond prejudice: Are negative evaluations the problem and is getting us to like one another more the solution? Behavioural and Brain Sciences, 35(6), 411-466.

Doosje, B., \& Branscombe, N. R. (2003). Attributions for the negative historical actions of a group. European Journal of Social Psychology, 33, 235-248. 
Doise, W., Mugny, G., \& Perret-Clermont, A. N. (1976). Social interaction and cognitive development: Further evidence. European Journal of Social Psychology, 6, 245-247.

Duveen, G. (2001). Representations, identity, resistance. In K. Deaux \& G. Philogene (Eds.), Representations of the social (pp. 257-284). Oxford: Blackwell.

Duveen, G. (2002). Construction, belief, doubt. Psychologie et Societé, 3, $139-155$.

Duveen, G. (2007). Culture and social sepresentations. In J. Valsiner \& A. Rosa (Eds.), The Cambridge handbook of sociocultural psychology. Cambridge: CUP.

Duveen, G., \& Lloyd, B. (1990). Introduction. In G. Duveen \& B. Lloyd (Eds.), Social representations and the development of knowledge (pp. 1-10). Cambridge: Cambridge University Press.

Duveen, G., \& Psaltis, C. (2008). The constructive role of asymmetries in social interaction. In U. Mueller, J. Carpendale, N. Budwig \& B. Sokol (Eds.), Social life and social knowledge: Toward a process account of development (pp. 183-204). Mahwah, NJ: Lawrence Erlbaum.

Easterbrook, M., \& Vignoles, V. (2013). What does it mean to belong? Interpersonal bonds and intragroup similarities as predictors of felt belonging in different types of groups. European Journal of Social Psychology, 43(6), $455-462$.

Galtung, J. (2000). Conflict transformation by peaceful means: The Transcend method. United Nations.

Gillespie, A. (2008). Social representations, alternative representations and semantic barriers. Journal for the Theory of Social Behaviour, 38, 375-391.

Gillespie, A. (2015). Non-transformative social interaction. In C. Psaltis, A. Gillespie \& A. N. P Perret-Clermont (Eds.), Social relations in human and societal revelopment (pp. 97-113). London: Palgrave Macmillan.

Goldberg, T. (2013). "It's in my veins": Identity and disciplinary practice in students' discussions of a historical issue. Theory \& Research in Social Education, $41(1), 33-64$.

Grever, M., \& Stuurman, S. (Eds.). (2007). Beyond the canon: History for the twenty-first century. Basingstoke: Palgrave Macmillan.

Halperin, E., Russell, A. G., Trzesniewski, K. H., Gross, J. J., \& Dweck, C. S. (2011). Promoting the Middle East peace process by changing beliefs about group malleability. Science, 333, 1767-1769.

Hammack, P. (2010). Identity as burden or benefit? Youth, historical narrative, and the legacy of political conflict. Human Development, 53, 173-201.

Hein, L., \& Selden, M. (Eds.). (2000). Censoring history: Citizenship and memory in Japan, Germany, and the United States. New York: M.E. Sharpe. 
Hobsbawm, E. (2002, February 23). War and peace: Newspaper article published in The Guardian. Retrieved September 21, 2016 from https:// www.theguardian.com/education/2002/feb/23/artsandhumanities.highereducation.

Howarth, C., Wagner, W., Kessi, S., \& Sen, R. (2012). The politics of moving beyond prejudice. Behavioural and Brain Sciences, 35(6), 437-438.

Imhoff, R., Bilewicz, M., \& Erb, H. P. (2012). Collective guilt versus collective regret. Different emotional reactions to ingroup atrocities. European Journal for Social Psychology, 42, 729-742.

Kadianaki, I., \& Andreouli, E. (2015), Essentialism in social representations of citizenship: An analysis of Greeks' and Migrants' discourse. Political Psychology. Advance online publication. doi: 10.1111/pops.12271.

Kadianaki, I., Andreouli, E., \& Carretero, M. (2016). Using national history to construct the boundaries of citizenship: An analysis of Greek citizens' discourse about immigrants' rights. Qualitative Psychology. http://dx.doi. org/10.1037/qup0000087.

Kelman, H. C. (2004). Reconciliation as identity change: A social psychological perspective. In Y. Bart-Siman-Tov (Ed.), From conflict resolution to reconciliation (pp. 111-124). Oxford: Oxford University Press.

Kelman, H. C. (2008). Reconciliation from a social-psychological perspective. In A. Nadler, T. Malloy \& J. D. Fisher (Eds.), Social psychology of intergroup reconciliation (pp. 15-32). Oxford: Oxford University Press.

Kitson, A. (2007). History teaching and reconciliation in Northern Ireland. In E. A. Cole (Ed.), Teaching the violent past: History education and reconciliation (pp. 123-155). Lanham, MD: Rowman \& Littlefield.

Klein, O. (2013). The lay historian: How ordinary people think about history. In R. Cabecinhas \& L. Abadia (Eds.), Narratives and social memory: Theoretical and methodological approaches (pp. 25-45). Braga, Portugal: University of Minho.

Klerides, E., \& Philippou, S. (2015). Cyprus: Exploring educational reform 2004-2014. In T. Corner (Ed.), Education in the European Union: Post-2003 member states (pp. 51-73). London: Bloomsbury.

Klerides, E., \& Zembylas, M. (2017). Ideology as immunology: History teaching in two ethnic borders of Europe. Compare: A Journal of Comparative and International Education, $47(3), 416-433$.

Korostelina, K., \& Lässig, S. (Eds.). (2013). History education and postconflict reconciliation: Reconsidering joint textbook projects. Abingdon, UK: Routledge.

Leach, C., Zeineddine, F., \& Čehajić-Clancy, S. (2013). Moral immemorial: The rarity of self-criticism for previous generations' genocide or mass violence. Journal of Social Issues, 69(1), 34-53.

Lederach, J. P. (1997). Building peace: Sustainable reconciliation in divided societies. Washington, D.C: United States Institute of Peace Press. 
Licata, L., \& Klein, O. (2010). Holocaust or benevolent paternalism? Intergenerational comparisons on collective memories and emotions about Belgium's colonial past. International Journal of Conflict and Violence, 4(1), $45-57$.

Liu, J. H., \& Hilton, D. J. (2005). How the past weighs on the present: Social representations of history and their role in identity politics. British Journal of Social Psychology, 44, 537-556.

Loizides, N. (2015). Designing peace: Cyprus and institutional innovations in divided societies. Pennsylvania: University of Pennsylvania Press.

Lowenthal, D. (1996). The heritage crusade and the spoils of history. Cambridge: CUP.

Makriyianni, C., \& Psaltis, C. (2007). History teaching and reconciliation. Cyprus Review, 19, 43-69.

Makriyianni, C., Psaltis, C., \& Latif, D. (2011). History teaching in cyprus. In E. Erdmann \& W. Hasberg (Eds.), Facing mapping, bridging diversity: Foundations of a European discourse on history education, part 1 (pp. 91-138). Germany: Wochen Schau Wissenschaft.

Marková, I., \& Gillespie, A. (Eds.). (2012). Trust and conflict: Representation, culture and dialogue. London: Routledge.

Martinovic, B., \& Verkuyten, M. (2013). 'We were here first, so we determine the rules of the game': Autochthony and prejudice towards out-groups. European Journal of Social Psychology, 43, 637-647.

McCully, A. (2012). History teaching, conflict and the legacy of the past. Education, Citizenship and Social Justice, 7(2), 145-159.

McCully, A., \& Barton, K. C. (2010). "You can form your own point of view": Internally persuasive discourse in Northern Ireland students' encounters with history. Teachers College Record, 112(1), 142-181.

Moscovici, S. (1976). Social influence and social change. London: Academic Press.

Moscovici, S. (1998/2000). The history and actuality of social representations. In G. Duveen (Ed.), Social representations: Explorations in social psychology. (pp. 120-154). Cambridge: Polity Press.

Moscovici, S., Jovchelovitch, S., \& Wagoner, B. (2013). (Eds.), Development as a social process: Contributions of Gerard Duveen. UK: Routledge.

Moscovici, S. (1961/2008). Psychoanalysis: Its image and its public. Cambridge: Polity Press.

Nadler, A., \& Shnabel, N. (2015). Intergroup reconciliation: Instrumental and socio-emotional processes and the needs-based model. European Review of Social Psychology, 26, 93-125.

Nasie, M., Bar-Tal, D., Pliskin, R., Nahhas, E., \& Haperin, E. (2014). Overcoming the barrier of narrative adherence in conflicts through awareness of the psychological bias of naive realism. Personal and Social Psychology Bulletin, 40, 1543-1557. 
Noor, M., Shnabel, N., Halabi, S., \& Nadler, A. (2012). When suffering begets suffering: The psychology of competitive victimhood between adversarial groups in violent conflicts. Personality and Social Psychology Review, 16(4), 351-374.

Obradovic, S., \& Howarth, C. (2017). Everyday Reconciliation. In C. Howarth \& E. Andreouli (Eds.), The social psychology of everyday politics. UK: Routledge. Papadakis, Y. (2008). Narrative, memory and history in divided Cyprus: A comparison of school books on the history of cyprus. History \& Museum, 20, 128-148.

Páez, D., \& Liu, J. H. (2011). Collective memory of conflicts. In D. Bar-Tal (Ed.), Intergroup conflicts and their resolution: A social psychological perspective (pp. 105-124). New York, NY: Psychology Press.

Páez, D., Bobowic, M., \& Liu, J. H. (2017). Social representations of the past and competences in history education. In M. Carretero, S. Berger \& M. Grever (Eds.), Handbook of research in historical culture and history education (pp. 491-510). Palgrave Macmillan.

Paulson, J. (2015). "Whether and how?" History education about recent and ongoing conflict: A review of research. Journal on Education in Emergencies, I(1), 14-47.

Perikleous, L. (2010). At a crossroad between memory and thinking: The case of primary history education in the Greek cypriot educational system, education 3-13: International Journal of Primary. Elementary and Early Years Education, 38(3), 315-328.

Perikleous, L., \& Shemilt, D. (Eds.). (2011). The future of the past: Why history education matters. Nicosia: AHDR.

Pettigrew, T. F. (1979). The ultimate attribution error: Extending Allport's cognitive analysis of prejudice. Personality and Social Psychology Bulletin, 5, 461-476.

Psaltis, C. (2012a). Intergroup trust and contact in transition: A social representations perspective on the Cyprus conflict. In I. Markova \& A. Gillespie (Eds.), Trust and conflict: Representations, culture and dialogue (pp. 83-104), London: Routledge.

Psaltis, C. (2012b). Culture and social representations: A continuing dialogue in search for heterogeneity in social developmental psychology. Culture of Psychology, 18(3), 375-390.

Psaltis, C. (2015a). Genetic social psychology: From microgenesis to ontogenesis and sociogenesis... and back. In C. Psaltis, A. Gillespie \& A. N. P PerretClermont (Eds.), Social relations in human and societal development, UK: Palgrave, Macmillan.

Psaltis, C. (2015b). Communication and the microgenetic construction of knowledge. In G. Sammut, E. Andreouli, G. Gaskell \& J. Valsiner (Eds.), Handbook of social representations (pp. 113-127). Cambridge: CUP. 
Psaltis, C. (2016). Collective memory, social representations of intercommunal relations and conflict transformation in divided Cyprus. Peace and Conflict: Journal of Peace Psychology, 22(1), 19-27.

Psaltis, C., \& Cakal, H. (2016). Social identity in divided Cyprus. In S. McKeown, R. Haji \& N. Ferguson (Eds.), Understanding peace and conflict through social identity theory: Contemporary and world-wide perspectives (Springer Peace Psychology Book Series) (pp. 229-244). UK: Springer.

Psaltis, C., Gillespie, A., \& Perret-Clermont, A. N. P. (Eds.). (2015). Human relations in human and societal development. UK: Palgrave-Macmillan.

Piaget, J. (1932/1997). The moral judgment of the child. New York: Free Press Paperbacks.

Pingel, F. (2016). Textbook revision programme: History, concepts, and assumptions. In A. Kulnazarova \& C. Ydesen (Eds.), UNESCO without borders. Educational campaigns for international understanding (pp. 13-31). New York: Routledge.

Rüsen, J. (2004). Historical consciousness: Narrative structure, moral function, and ontogenetic development. In P. Seixas (Ed.), Theorizing historical consciousness (pp. 63-85). Toronto: University of Toronto Press.

Sani, F. (2008). Self continuity: Individual and collective perspectives. New York: Psychology Press.

Seixas, P. (Ed.). (2004). Theorizing historical consciousness. Toronto: University of Toronto Press.

Shnabel, N., \& Ullrich, J. (2016). Putting emotion regulation in context: The (Missing) role of power relations. Intergroup Trust, and Groups' Need for Positive Identities in Reconciliation Processes. Psychological Inquiry, 27(2), 124-132.

Smeekes, A. (2015). National nostalgia: A group-based emotion that benefits the in-group but hampers intergroup relations. International Journal of Intercultural Relations, 49, 54-67.

Smeekes, A., \& Verkuyten, M. (2015). The presence of the past: Identity continuity and group dynamics. European Review of Social Psychology, 26(1), 162-202.

Smeekes, A., McKeown, S., \& Psaltis, C. (2017). Endorsing narratives under threat: Maintaining perceived collective continuity through the protective power of ingroup narratives in Northern Ireland and Cyprus. Journal of Social and Political Psychology.

Smith, E. R. (1993). Social identity and social emotions: Toward new conceptualizations of prejudice. In D. M. Mackie \& D. L. Hamilton (Eds.), Affect, cognition, and stereotyping: Interactive processes in group perception (pp. 297-315). San Diego, CA: Academic Press.

Stephan, W. G., Ybarra, O., \& Rios Morrison, K. (2009). Intergroup threat theory (pp. 43-59). In T. Nelson (Ed.), Handbook of prejudice. Mahwah, NJ: Lawrence Erlbaum Associates. 
Tajfel, H. (Ed.). (1978). Differentiation between social groups: Studies in the social psychology of intergroup relations. London: Academic Press.

Tajfel, H., \& Turner, J. C. (1979). An integrative theory of intergroup conflict. In W. G. Austin \& S. Worchel (Eds.), The social psychology of intergroup relations (pp. 7-24). Monterey, CA: Brooks-Cole.

Tausch, N., Hewstone, M., Kenworthy, J., Psaltis, C., Schmid, K., Popan, J., et al. (2010). Secondary Transfer Effects of Intergroup Contact: Alternative Accounts and Underlying Processes. Journal of Personality \& Social Psychology, 99, 282-302.

Tint, B. (2010a). History, memory, and intractable conflict. Conflict Resolution Quarterly, 27, 239-256.

Tint, B. (2010b). History, memory, and conflict resolution: Research and application. Conflict Resolution Quarterly, 27, 369-399.

Vollhardt, J. R., \& Twali, M. S. (2016). Emotion-based reconciliation requires attention to power differences, critical consciousness, and structural change. Psychological Inquiry, 27, 136-143.

Wagoner, B. (2015). Collective remembering as a process of social representations. In G. Sammut, E. Andreouli, G. Gaskell, \& J. Valsiner (Eds.), Cambridge handbook of social representations (pp. 143-162). Cambridge: Cambridge University Press.

Wineburg, S. (2001). Historical thinking and other unnatural acts. Philadelphia: Temple University Press.

Van Zomeren, M., Postmes, T., \& Spears, R. (2008). Toward an integrative social identity model of collective action: A quantitative research synthesis of three socio-psychological perspectives. Psychological Bulletin, 134, 504-535.

Van Alphen, F., \& Carretero, M. (2015). The construction of the relation between national past and present in the appropriation of historical master narratives. Integrative Psychological and Behavioral Science., 49(3), 512-530.

Zittoun, T., Duveen, G., Gillespie, A., Ivinson, G., \& Psaltis, C. (2003). The use of symbolic resources in developmental transitions. Culture \& Psychology, 9, $415-448$.

Zeromskyte, R., \& Wagner, W. (2016). When a majority becomes a minority: Essentialist intergroup stereotyping in an inverted power differential. Culture \& Psychology. 23, 1, 88-107. 


\section{Authors' Biography}

Charis Psaltis is an Associate Professor of Social and Developmental Psychology at the University of Cyprus. His research interests fall in the areas of genetic social psychology, social interaction in learning and cognitive development, social representations of gender, intergroup contact and intergroup relations between Greek Cypriots and Turkish Cypriots, development of national identities and history teaching and collective memory. He published papers in Journal of Personality and Social Psychology, European Journal of Social Psychology, British Journal of Developmental Psychology, Culture \& Psychology and Human Development. Since 2014, he is a member of the Editorial Board of the British Journal of Developmental Psychology and since 2015 Associate Editor of European Journal of Psychology of Education. In April 2014, his book co-authored with Anna Zapiti entitled Interaction, Communication and Development: Psychological Development as a social process was published by Routledge, and in 2015, his coedited volume Social Relations in Human and Societal Development by Palgrave Macmillan.

Mario Carretero is a Professor of Cognitive Psychology at Autonoma University of Madrid, Spain, where he was Dean of the Faculty of Psychology, and Researcher at FLACSO, Argentina. He has carried out an extensive research on history education from both cognitive and sociocultural approaches. He has published in Journal of the Learning Sciences and Cognition and Instruction. His last books are History Education and the Construction of National Identities (2012) (co-ed.) and Constructing Patriotism (funded by the Guggenheim Foundation) (2011). He has been Santander Visiting Scholar at the David Rockefeller Center for Latin American Studies of Harvard University (2009) and Bliss Carnochan Visiting Professor at the Humanities Center of Stanford University (2011). His present research interests have to do with an interdisciplinary attempt to study history education issues as it can be seen in Palgrave Handbook of Research in Historical Culture and Education (2017) (co-edited along with S. Berger and M. Grever).

Sabina Čehajić-Clancy works as an Associate Professor of Social and Political Psychology at the Sarajevo School of Science and Technology in Bosnia and Herzegovina. She works in the field of intergroup relations, more specifically on reconciliation in post-conflict societies. She has published numerous papers in peer-reviewed journals such as Journal of Personality and Social Psychology, European Journal of Social Psychology, Political Psychology, Group Processes and Intergroup Relations and Psychological Inquiry. Sabina has also over thirteen years of experience in working as an expert consultant for various international and 
local NGOs such as UNICEF, UNDP, Post-conflict Research Centre, Catholic Relief Service, Save the Children and USAID designing and evaluating reconciliation-oriented interventions. Her work has received wide media coverage due to its unique methodological approaches used in (post-)conflict contexts. She is also a member of the Editorial Board for the Political Psychology Journal.

Open Access This chapter is licensed under the terms of the Creative Commons Attribution 4.0 International License (http://creativecommons.org/licenses/ by $/ 4.0 /$ ), which permits use, sharing, adaptation, distribution and reproduction in any medium or format, as long as you give appropriate credit to the original author(s) and the source, provide a link to the Creative Commons license and indicate if changes were made.

The images or other third party material in this chapter are included in the chapter's Creative Commons license, unless indicated otherwise in a credit line to the material. If material is not included in the chapter's Creative Commons license and your intended use is not permitted by statutory regulation or exceeds the permitted use, you will need to obtain permission directly from the copyright holder.

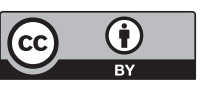

